\title{
Recent Progresses on Industrialization of Sweet Sorghum at IMP
}

\author{
Xicun Dong ${ }^{1}$, Wenjian $\mathrm{Li}^{1}$, Ruiyuan $\mathrm{Liu}^{1} \&$ Wenting $\mathrm{Gu}^{1}$ \\ ${ }^{1}$ Department of Radiobiology, Institute of Modern Physics, Chinese Academy of Sciences, Lanzhou, China \\ Correspondence: Xicun Dong, Radiobiology Department, Institute of Modern Physics, Chinese Academy of \\ Sciences, Lanzhou, China. Tel: 86-0931-496-9175. E-mail: dongxicun@impcas.ac.cn
}

Received: June 11, 2017

doi:10.5539/jas.v9n10p57
Accepted: July 30, $2017 \quad$ Online Published: September 15, 2017

URL: https://doi.org/10.5539/jas.v9n10p57

The research is financed by the Western Light Co-scholar (29Y406020) Program of the Chinese Academy of Sciences.

\begin{abstract}
Sweet sorghum [Sorghum bicolor (L.) Moench] is not only an efficient and highly productive bioenergy crop that may help alleviate potential food-fuel tension caused by over-reliance on corn grain ethanol because of its outstanding features, including large amounts of fermentable carbohydrates in its juice-rich stalks, drought-tolerance, saline-alkaline resistance but also has considerable potential as food, forage crop owing to the limited availability of arable land. In this review, we have provided a brief overview of the progress that has been made in sweet sorghum industrialization at IMP range from research motivation, breeding, planting scale to products development. A conclusion is drawn that sweet sorghum industry is a systematic project, involving many key points, such as breeding, planting, production process and products sale. From a strategic and sustainability point of view, sweet sorghum is one of the most promising plants, particularly for ethanol, silage and liquor production.
\end{abstract}

Keywords: breeding, large-scale planting, products development, sweet sorghum

\section{Introduction}

The population growth, changes in the life style, and the rise in the man's living standards have all led to an increase in the energy consumption in the world. Bioenergy production systems, as a part of the solution to this problem, have attracted much attention in recent years because they can be appropriated substitutes for the traditional energy production systems which are, in addition to being finite and nonrenewable, associated with environmental problems (Sathre, 2014; Hamid et al., 2016) as well. Plants have the unique ability to convert the incoming flux of solar energy, a renewable form of energy, into useful biomass, in the form of food, feed and fuel. However, in order to fully exploit the potential of crops for transforming solar energy into dry matter, crops need to be supplemented with fossil energy (Pimentel, 1992; Enrico, 2007). By the early 1970s, the energy crisis stimulated a renewed interest in producing energy from crop biomass. In addition, evidence indicates that this massive use of fossil energy has increased the concentration of $\mathrm{CO}_{2}$ and other greenhouse gases in the Earth's atmosphere. This has also become a concern because of the potential long-term influence on global climate change (IPCC, 1996). Given the increased demand for renewable fuels, the search for new sources of raw materials for use in the field of bioenergy also increased, largely those wastes from agro-industrial processes. Ethanol has excellent fuel properties for spark ignition internal combustion engines; for example, its high octane and high heat of vaporization make the alcohol more efficient as a pure fuel than gasoline. In addition, ethanol has a very low toxicity, particularly in comparison to other fuels, and is readily biodegradable in water and soils (Bailey, 1996; Gnansounou et al., 2005). Currently, bioethanol is the most promising alternative renewable energy source to petroleum production. Equally important, bioethanol has the potential to provide sustainable, cost effective energy while reducing greenhouse gas emissions (Carolina et al., 2016). With increasing energy demands and environmental pressure, interest in producing renewable energy from crop biomass is rapidly increasing worldwide, which ethanol produced from energy crops would benefit economic growth and energy security (Tilman et al., 2009; Wullschleger et al., 2010). However, some basic principles must be adhered to for the sustainable development of biofuels: operations must ensure the human right to adequate food and improve food security (RSB, 2013; Qiu et al., 2010; Fu et al., 2016). Sweet sorghum [Sorghum bicolor (L.) Moench] is an 
efficient and highly productive bioenergy crop option that may help alleviate potential food-fuel tension caused by over-reliance on corn grain ethanol because of its outstanding features (Rooney et al., 2007; Han et al., 2013), including large amounts of fermentable carbohydrates in its juice-rich stalks (Antonopoulou et al., 2008; Bennett \& Anex, 2008; Zhao et al., 2009), drought-tolerance, saline-alkaline resistance (Vasilakoglou et al., 2011). It also has favorable sustainability characteristics (De Vries et al., 2010). In developed countries, sweet sorghum has considerable potential as forage, energy and biomass crop, while in developing countries the combination of biomass, biofuel and high yield could be used to tackle the growing and competing need for food, feed and fuel owing to the limited availability of arable land (Mocoeur et al., 2015). The Institute of Modern Physics (IMP), Chinese Academy of Sciences has established industrial chain based on circular economic to develop ethanol, yeast glucan and silage for sweet sorghum as raw materials since 2006 (Figure 1) (Dong \& Li, 2008).

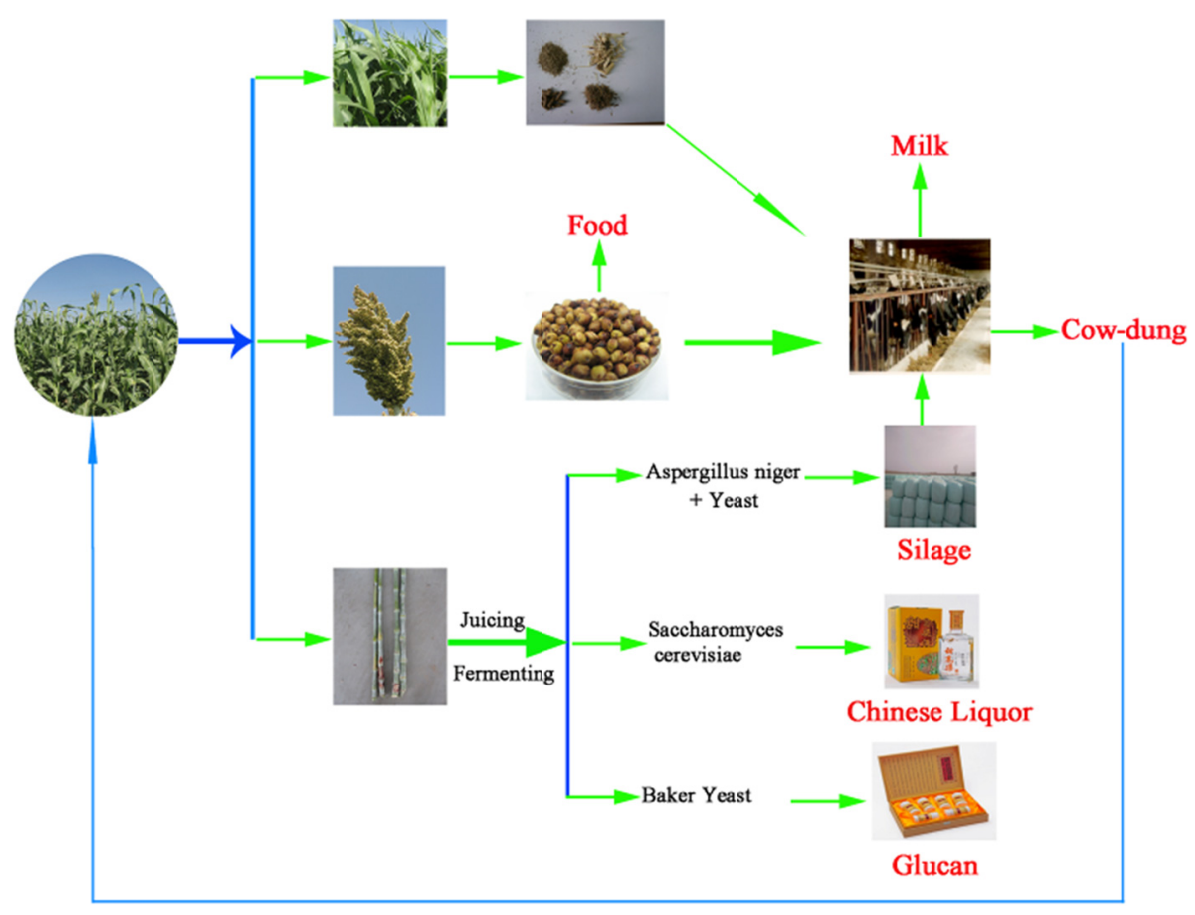

Figure 1. Industrial chain for sweet sorghum at IMP

\section{Research Motivation}

Given the strong need for renewable energy, the production of large quantities of biomass crops for fuels could require an extensive amount of land. However, information documenting the long-term environmental impacts of converting agricultural lands to bioenergy crop production is lacking (Nyakatawa et al., 2006; Fu et al., 2016). It is official policies that require the use of non-food plants and nonfarm land for energy crop production so as not to affect food security or the environment because of fairly limited cultivated land resources in China (Kou et al., 2008; Wang, 2005). Gansu province is located in northwest of China. Total land area of Gansu is 454 thousand square kilometers, accounting for the seventh of China's total territory. The land area suited to cultivation accounts for 46.27 billion ha. The plant base of sweet sorghum lies in the Hexi Corridor in Gansu, which Hexi Corridor is very dry with annual precipitation from about $200 \mathrm{~mm}$ in the east (Gulang county) to $<50 \mathrm{~mm}$ in the west (Dunhuang city). Ample sunlight, several inland-rivers, and flat landform result in the region having huge agricultural potential (Li et al., 2006). For Hexi Corridor, annual accumulated temperature above $10{ }^{\circ} \mathrm{C}$ is from $2500{ }^{\circ} \mathrm{C}$ to $3600{ }^{\circ} \mathrm{C}$, annual radiation value is $5800-6400 \mathrm{MJ} / \mathrm{m}^{2}$, annual sunshine duration can reach 2800 to 3300 hours. Through analyzing the space-time distribution characters of natural resources of high yield areas in Gansu (Wang et al., 2007), the results indicated that the areas are generally abundant in natural resources; photosynthetic potency accessed $16468.5 \mathrm{~kg} / \mathrm{hm}^{2}$. Therefore, it is very good for the nutrition growth of sweet sorghum because of the abundant sunshine and heat resource. IMP was founded in 1957 in Lanzhou, which is the capital of Gansu Province, China (Li, 2007; Wang, 2006). The Heavy Ion Research Facility in Lanzhou (HIRFL) is one of the ion-beam acceleration facilities intensively used in the past two decades at IMP (Sun et al., 2003). A 
lot of experiments irradiated by heavy ion beam have been carried out in the HIRFL. Due to its higher mutation rate and wider mutation spectrum with lower damage to irradiated materials (Abe et al., 2000; Tanaka, 1999), mutation breeding technology induced by heavy ion beam has been used to improve sweet sorghum variety and microbial strain since the implementation of sweet sorghum industrialization at IMP to add incomes of farmers in rural area and promote the development of regional economy.

\section{Improvement of Sweet Sorghum Variety}

Great efforts have to be made in order to produce a storable biomass feedstock for the ethanol plant. In general, the choice of the sweet sorghum variety is of great importance and depends among others on climate-and soil conditions as well as on harvesting and processing technologies. Especially, the higher tolerance towards insufficient water supply may be an important factor (Theuretzbacher et al., 2013). Thus, optimize seed may facilitate large-scale production of sweet sorghum for bioenergy (Rutto et al., 2013). To breed novel varieties to provide quality raw materials for bio-ethanol production from sweet sorghum, more work has been done for mutation breeding with carbon ion beam irradiation in sweet sorghum since 2006 (Dong et al., 2007). At IMP, the dry seeds of sweet sorghum were irradiated by carbon ion beam with different doses (Dong et al., 2007, 2008), which higher mutation frequencies of $9.1 \%, 8.1 \%$ and $8.5 \%$, were found for stalk thickening, sugar content and plant withering, respectively. Importantly, an early-maturity mutant, KFJT-1, was acquired after 80Gy carbon ion irradiation, which the growth period was stably shortened for around 20 days compared to wild-type plant, KFJT-CK (Dong et al., 2012). Moreover, our study indicated that KFJT-1 was able to not only flower but also produce mature grain, which an insert fragment GA was found in KFTJ-1 and the corresponding fragment was not found in KFJT-CK for the $H d 3 a$ gene by further research (Dong et al., 2015). Functional analysis of gene ontology indicated that genes involved flowering time were also enriched such as "response to far red light", "pollen development" including "auxin transport", which consist with the short growth cycle of KFJT-1 compared to KFJT-CK (Dong et al., 2017). At present, KFJT-1 has been identified by the Gansu provincial variety Approval Committee after regional trial and production test for several years (Dong et al., 2016), which can solve the difficult problem of earlier frost during industrialization plant for bio-ethanol production using sweet sorghum as feedstock in the northwest region of China. In addition, Gu et al. (2016) evaluated the productivity of KF1210-3 and KF1210-4 induced by carbon ion irradiation which were grown in intermediate $\left(4.6 \mathrm{dSm}^{-1}\right)$ and high $\left(11.9 \mathrm{dSm}^{-1}\right)$ soil salinity, indicating that KF1210-3 and KF1210-4 were highly tolerant to soil salinity stress compared to wild-type plant.

\section{Planting Scale of Sweet Sorghum}

Aiming at investigating adaptability of sweet sorghum, field trials were carried out under different climatic conditions in China from 2006 to 2012, which soil types are mainly light loam, saline-alkali land and desert land, the altitude varied range from 6.5 to 2500 meter, including Gansu province, Qinghai province, Xinjiang province, Hainan province, etc., the number being totally 11 provinces (Figure 2) (Dong, 2011). In the case of planting scale, great changes have taken place since 2013, which a deep cooperation agreement was signed between IMP and Wuwei municipal government, Gansu province. Since then, sweet sorghum has been systemically studying from breeding, weed control to cultivation technique (Table 1). So far, planting scale of sweet sorghum has approximately been to 75 thousand $\mathrm{hm}^{2}$ in Gansu Province. According to developmental plan of sweet sorghum industrialization in Wuwei city, sweet sorghum will be planted to 330 thousand $\mathrm{hm}^{2}$ in Gansu Province in 2020, forming industrial chain of hundred billion yuan. 


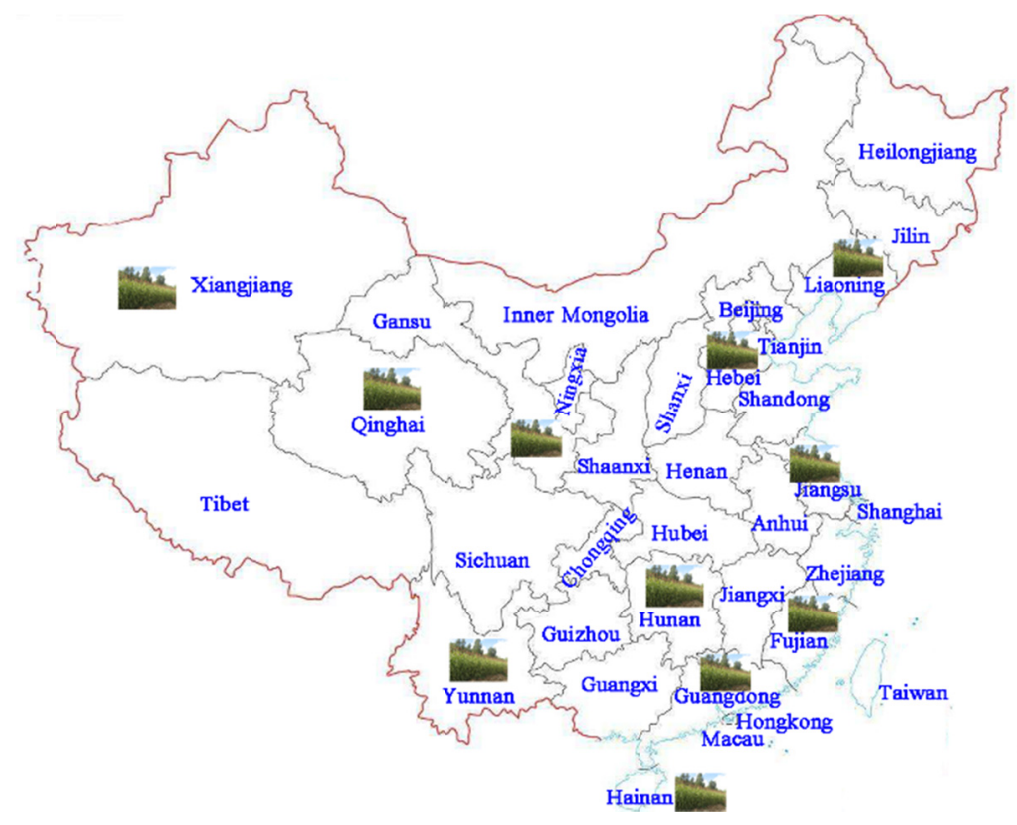

Figure 2. Ecological adaptability trials of sweet sorghum were carried out by IMP at different climatic conditions in China

\section{Improvement of Microbial Strain}

Most microorganisms used in production are usually hard to be improved because of its resistance to the old mutation methods (Wu et al., 1999). As a new way, heavy ion beam shows very good effects in microbial strain improvement at IMP, which firstly evaluated biological action of microorganism exposed to charged particles during induction of inactivation and mutation in a red yeast strain (Rhodotorula glutinis AY) by carbon beams of different LET values (14.9-120.0 KeV $\mathrm{m}^{-1}$ ) and found that survival curves were exponential, and mutation curves were linear for all LET values (Wang et al., 2010).

Table 1. Sweet sorghum was been systemically studied range from breeding, weed control to cultivation technique

\begin{tabular}{|c|c|c|c|}
\hline Research content & Method & Achieved results & References \\
\hline \multicolumn{4}{|l|}{ Breeding } \\
\hline Mutant phenotypic variation & Carbon ions irradiation & Early-maturity mutant KFJT-1 & Dong et al., 2012 \\
\hline Mutant evaluation & Carbon ions irradiation & Early-maturity mutant KF1210-3 & Gu et al., 2016 \\
\hline Introducing breeding & Comparison test & BJ0602, BJ0603 & Wang et al., 2013 \\
\hline \multicolumn{4}{|l|}{ Cultivation Technique } \\
\hline Suitable planting division & $\begin{array}{l}\text { Cultivated Land Resources } \\
\text { Management Information Systems }\end{array}$ & $\begin{array}{l}\text { The most suitable planting } \\
\text { area covers } 48.01 \%\end{array}$ & Ning \& Guo, 2015 \\
\hline Fertilizing methods & Different level fertilization & $\begin{array}{l}\text { For forage sorghum, N } 562.5 \mathrm{~kg} / \mathrm{ha} \text {, } \\
\mathrm{P}_{2} \mathrm{O}_{5} 150 \mathrm{~kg} / \mathrm{ha}, \mathrm{K}_{2} \mathrm{O} 120 \mathrm{~kg} / \mathrm{ha} \text {. } \\
\text { For alcohol sorghum, N } 375 \mathrm{~kg} / \mathrm{ha} \text {, } \\
\mathrm{P}_{2} \mathrm{O}_{5} 150 \mathrm{~kg} / \mathrm{ha}, \mathrm{K}_{2} \mathrm{O} 180 \mathrm{~kg} / \mathrm{ha} \text {. }\end{array}$ & Zhang \& Sun, 2015 \\
\hline Planting pattern & Film mulching & Watering after sowing & Wang \& Yin, 2015 \\
\hline Planting density of forage sweet sorghum & Randomized block design & $166755-192405$ plants/ha & Zhang et al., 2016 \\
\hline Stubble processing & $\begin{array}{l}\text { Deep scarification, } \\
\text { fertilization and compaction }\end{array}$ & Effectively solve the stubble & Ren, 2015 \\
\hline \multicolumn{4}{|l|}{ Weed Control } \\
\hline Effect of black film mulching on weed control & Black film mulching & The efficacy being $100 \%$ & Zhang, 2015 \\
\hline Herbicides screening & Randomized block design & $38 \%$ atrazine suspending agent & Li \& Lv, 2015 \\
\hline Atrazine concentration determination & Different concentrations spraying & $\begin{array}{l}\text { The most effective } \\
\text { concentration being } 2.85 \mathrm{~kg} / \mathrm{ha}\end{array}$ & Wang et al., 2016 \\
\hline
\end{tabular}


Based on these results, Chen et al. (2010) screened high-producing-avermetin-Bla strain ZJAV-Y203 from the original strain Streptomyces avermitilis (ZJAV-A1) irradiated by carbon ion beam with different doses, the Bla component increased by $51.43 \%$. In recent years, a high-yielding citric acid mutant, HW2, was obtained from Aspergillus niger induced by carbon ion irradiation which can accumulate $118.9 \mathrm{~g} / \mathrm{L}$ citric acid with a residual total sugar concentration of only $14.4 \mathrm{~g} / \mathrm{L}$ in a 10-L bioreactor (Hu et al., 2016). Zhou et al (2016) investigated the utility of two rounds of heavy ion beam irradiation to create Clostridium tyrobutyricum mutants with improved bioproduction capability under acidic conditions and revealed that carbon ions effectively induced the expression of key enzymes in glycolysis, product formation, energy and redox metabolism and the cellular response to butyric acid production. Moreover, a novel strain capable of producing large amounts of n-butanol called ACKKO-adhE2 was obtained via advanced metabolic engineering and synthetic biology technologies (Zhou et al., 2016; Jiang et al., 2009; Yu et al., 2011). In terms of sweet sorghum industrialization, fermentation process development has been very important for efficient ethanol production (Bai et al., 2004; Laopaiboon, 2007). At present, Saccharomyces cerevisiae is widely used in industrial ethanol production (Zhao \& Bai, 2009). However, ethanol produced by yeast is toxic to the yeast itself. To achieve high-level ethanol production, yeast strains that can produce and tolerate high ethanol concentration should be used (Phukoetphim et al., 2017). Thus, industrial microbes often need to be improved in order to maintain or raise production. Importantly, conversion of sweet sorghum juice to ethanol can be accomplished either by fermenting the juice or by fermenting the chopped stalks in a solid state process (Regassa \& Wortmaan, 2014). The former is called liquid-state fermentation of sweet sorghum, which the method is technically simple and mature, the loss of total sugar during the pressing procedure (Wu et al., 2010), low ethanol fermentation content, and large amount of wastewater from fermentation further increase production costs (Kwon et al., 2011; Gibbons et al., 1986). The latter is called solid-state fermentation of sweet sorghum, which the method is gaining more attention because of the higher sugar utilization and ethanol yield, lower energy expenditure and capital, and reduced water usage and wastewater output (Kargi et al., 1985; Rein, 1984). To enhance bioethanol production from sweet sorghum as feedstock, Saccharomyces cerevsiea strains were irradiated by $100 \mathrm{MeV} / \mu$ carbon ion beam at IMP, resulting in isolating a high producing-ethanol mutant, $\mathrm{C} 03 \mathrm{~A}$, from original stains, which the ethanol fermentation could be completed in 36 hours and the production of ethanol was to $13.2 \%(V / V)$, fermentation time being shortened 12 hours and increased ethanol yield by $1.6 \%$ compared to original strain, respectively ( $\mathrm{Lu}$ et al., 2010). According to the requirement of yeast glucan production, seven mutant strains with high-yielding $\beta$-glucan were obtained from original baker yeast induced by $80 \mathrm{MeV} / \mu$ carbon ion beam, among which the yield of mutant strain, YH-11, was 1.73 times higher than the original strain, the value being $1.48 \mathrm{mg} / \mathrm{mL}$ (Li et al., 2017). In addition, Wang et al. (2013) developed compound microbial agent from the protein-enriched yeast and cellulose-enriched Aspergillus niger irradiated by carbon ion beam.

\section{Products for Sweet Sorghum as Raw Material}

It is well known that the raw materials of high quality are the focus and life line of sweet sorghum industrialization. In recent years, the three varieties were obtained after several years' selection, among which one was acquired by carbon ion irradiation (Dong et al., 2012), the other was isolated from more than 30 sweet sorghum varieties via introduction breeding. At present, more attention is mainly paid to ethanol (Dong, 2011), $\beta$-glucan (Li et al., 2017) and silage (Wang et al., 2014) using sweet sorghum as feedstock at IMP. For ethanol production, liquid-state fermentation technology was not only put into use, but also a high producing-ethanol mutant, C03A, was obtained, the ethanol yield reaching $13.2 \%(V / V)$, increased by 1.6\% (Lu et al., 2010). Based on these results, Chinese liquor was produced using sweet sorghum as feedstock. In order to improve the quality of sweet sorghum liquor, aroma components in Luzhou Laojiao 1573 liquor was investigated after electron beam irradiation (Zhang et al., 2013), indicating that 56 kinds of aroma components were detected by Gas Chromatogram from 1573 liquor, among which changes had taken in 41 kinds of aroma components via electron beam irradiation, mainly esters content declining and acid content rising in irradiated liquor, the change tendency similar to other high quality liquor brewing. For $\beta$-glucan, the production equipment has been upgraded at the production pilot base of Baiyin city and manufactured 1 ton products by using this line. To date, all indexes are in the leading level in China (Dong, 2011). To investigate radiation protection induced by carboxymethy- $\beta$-1,3-glucan which was manufactured at IMP, the effect of carboxymethy- $\beta 1,3$-glucan on Human B lymphoblasts (HMy2.CIR) was carried out in our laboratory (Ma et al., 2016). The results showed that carboxymethy- $\beta 1,3$-glucan was non-toxicity and protected HMy2.CIR cells against radiation, resulted in fewer DNA strand breaks, increasing surviving fraction, reducing apoptosis and micronucleus rate. In terms of silage production, suitable inoculants play a vital role on silage quality of sweet sorghum. Therefore, appropriate silage inoculants for sweet sorghum were selected at IMP (Dong et al., 2016). A conclusion was drawn that the compound microbial agents, FHI, FHIIL and FHIII, were the optimal inoculants, which were manufactured by 
IMP on its own. During production of silage, the compound microbial agent was firstly added at the proportion of $1 \%$ into sweet sorghum slag. Then, the humidity of the sweet sorghum slag should be kept in $60 \%$ to $65 \%$, which the ratio of sweet sorghum residue to water was 1:1. At last, fermentation was carried out in bags and cellar pits (Wang et al., 2013). The results indicated that sweet sorghum straw bio-feed fermented in bags and cellar pits by the compound microbial agent could both increase the content of the crude protein and reduce the content of the fibrinogen compared with control group. Further feeding experiment evaluated the advantage of sweet sorghum silage, the feed intake and milk yield increasing $11.4 \%$ and $14.2 \%$, respectively. In addition, the milk protein and milk fat content of experimental group increased by $14.03 \%$ and $16.3 \%$ compared the control group, respectively (Wang et al., 2013).

\section{Conclusions}

Sweet sorghum industrialization is a complete industrial chain, including variety and strain improvement, large-scale planting, stalk silage, juice fermentation, market research and sales of products, so sweet sorghum industrialization is a systematic project, associated with many techniques, such as breeding, cultivation, chemical process and biochemistry, etc. In this review, we have introduced the progress that has been made in sweet sorghum industrialization at IMP range from research motivation, breeding, planting scale to products development. In the process of industrialization, the total sweet sorghum output could be further increased by improving the performance of crop varieties because of the great potential for genetic improvement (Reddy et al., 2005; Zhao et al., 2012). In this study, an early-maturity mutant, KFJT-1, was acquired after 80Gy carbon ion irradiation, which the growth period was stably shortened for around 20 days compared to wild-type plant, KFJT-CK. To date, planting scale of sweet sorghum has approximately been to 75 thousand $\mathrm{hm}^{2}$ in Gansu Province. At the same time, the strains to produce ethanol, $\beta$-glucan and silage inoculants were obtained by heavy ion beam irradiation. In addition, high-producting strains of avermetin, citric acid and butyric acid were also isolated from original strains, respectively. From a strategic and sustainability point of view, sweet sorghum is one of the most promising plants, particularly for ethanol, silage and liquor production. We believe that sweet sorghum industrialization must be resulted in achieving economic benefits for local governments and enterprises in the future.

\section{References}

Abe, T., Bae, C. H., Ozaki, T., Wang, J. M., \& Yoshida, S. (2000). Stress-tolerant mutants induced by heavy-ion beams. Gamma Field Symp., 39, 45-46.

Antonopoulou, G., Gavala, H. N., Skiadas, I. V., \& Lyberatos, G. (2008). Biofuels generation from sweet sorghum: Fermentative hydrogen production and anaerobic digestion of the remaining biomass. Bioresource Technology, 99, 110-119. https://doi.org/10.1016/j.biortech.2006.11.048

Bai, F. W., Chen, L. J., Zhang, Z., Anderson, W. A., \& Moo-Young, M. (2004). Continuous ethanol production and evaluation of yeast cell lysis and viability loss under very high gravity medium conditions. $J$. Biotechnol., 110, 287-293. https://doi.org/10.1016/j.jbiotec.2004.01.017

Bailey, B. K. (1996). Performance of ethanol as a transportation fuel. In C. E. Wyman (Ed.), Handbook on Bioethanol: Production and Utilization, Applied Energy Technology Series (pp. 37-60). Taylor and Francis.

Bennett, A. S., \& Anex, R. P. (2008). Farm-gate production costs of sweet sorghum as a bioethanol feedstock. Transactions of the ASABE, 51, 603-613. https://doi.org/10.13031/2013.24360

Carolina, A. B., Roberto, N. M., Lidia, M. M., Santa, A., \& Nei, P. J. (2016). Sweet sorghum as a whole-crop feedstock for ethanol production. Biomass and Bioenergy, 94, 46-56. https://doi.org/10.1016/j.biombioe. 2016.08.012

Chen, J. H., Wang, S. Y., Liu, J., Li, W. J., Lang, J. P., \& Ma, X. Q. (2010). Mutation breeding of streptomyces avermitilis irradiated by heavy ion beam. Journal of Gansu Agricultural University, 3, 85-87.

De Vries, S. C., Van de, V. G., Van Ittersum, M. K., \& Giller, K. E. (2010). Resource use efficiency and environmental performance of nine major biofuel crops, processed by first-generation conversion techniques. Biomass and Bioenergy, 34, 588-601. https://doi.org/10.1016/j.biombioe.2010.01.001

Dong, M. Y., Wang, S. Y., Jiang, B. L., Li, W. J., \& Liu, J. (2016). Effects of different silage inoculants on silage quality of sweet sorghum silage. Feed Industry, 37, 28-31.

Dong, X. C. (2011). Rethinking the development of sweet sorghum industrialization in Gansu province. Gansu Science and Technology, 27, 1-2. 
Dong, X. C., \& Li, W. J. (2008). The advantages of developing sweet sorghum industrialization in Gansu Province. International Conference on Biomass Energy Technologies, Guangzhou, China.

Dong, X. C., \& Li, W. J. (2012). Biological features of an early-maturity mutant of sweet sorghum induced by carbon ions irradiation and its genetic polymorphism. Advances in Space Research, 50, 496-501. https://doi.org/10.1016/j.asr.2012.04.028

Dong, X. C., Li, W. J., He, J. Y., \& Yu, L. X. (2007). Current effect of irradiation with $12 \mathrm{C}+6$ ions beam on mutation of sweet sorghum. J. Radiat. Res. Radiat. Process, 6, 359-362.

Dong, X. C., Li, W. J., He, J. Y., Yu, L. X., \& Zhou, L. B. (2008). The influence of carbon ion irradiation on sweet sorghum seeds. Nuclear Instruments and Methods in Physics Research B, 266, 123-126. https://doi.org/10.1016/j.nimb.2007.10.025

Dong, X. C., Li, W. J., Liu, R. Y., \& Gu, W. T. (2015). Phenotypic variation of sweet sorghum after carbon ion beam irradiation. Res. On crops, 16, 162-169. https://doi.org/10.5958/2348-7542.2015.00023.6

Dong, X. C., Yan, X., \& Li, W. J. (2016). Plant mutation breeding with heavy ion irradiation at IMP. Journal of Agricultural Science, 8, 34-41. https://doi.org/10.5539/jas.v8n5p34

Dong, X. C., Yan, X., Li, W. J., Liu, R. Y., \& Gu, W. T. (2017). Tissue-specific expression profiling of seedling stage in early-maturity mutant induced by carbon ion beam in sweet sorghum. Journal of Agricultural Science, 9, 49-63. https://doi.org/10.5539/jas.v9n1p49

Enrico, C. (2007). Grasslands for bioenergy production. Agron. Sustain. Dev., 28, 47-55. https://doi.org/10.1051/ agro:2007034

Fu, H. M., Meng, F. Y., Molatudi, R. L., \& Zhang, B. G. (2016). Sorghum and switchgrass as biofuel feedstocks on marginal lands in northern China. Bioenerg. Res., 9, 633-642. https://doi.org/10.1007/s12155-0159704-0

Gibbons, W. R., Westby, C. A., \& Dobbs, T. L. (1986). Intermediate-scale, semicontinuous solid-phase fermentation process for production of fuel ethanol from sweet sorghum. Appl. Environ. Microb., 51, 115-122.

Gnansounou, E., Dauriat, A., \& Wyman, C. E. (2005). Refining sweet sorghum to ethanol and sugar: Economic trade-offs in the context of North China. Bioresource Technology, 96, 985-1002. https://doi.org/10.1016/ j.biortech.2004.09.015

Gu, W. T., Li, W. J., Liu, R. Y., Jin, W. J., Yang, T. L. W., \& Dong, X. C. (2016). Physiological property and yield of the sweet sorghum mutants induced by heavy ion irradiation. Nucl. Sci. Tech., 27, 88. https://doi.org/ $10.1007 / \mathrm{s} 41365-016-0086-6$

Hamid, G., Mir, S. P., \& Alireza, M. (2016). Biomass supply chain network design: An optimization-oriented review and analysis. Industrial Crops and Products, 94, 972-1000. https://doi.org/10.1016/j.indcrop. 2016.09.027

Han, K. J., Pitman, W. D., Kim, M., \& Aita, G. (2013). Ethanol production potential of sweet sorghum assessed using forage fiber analysis procedures. Global Change Biology Bioenergy, 5, 358-366. https://doi.org/ 10.1111/j.1757-1707.2012.01203.x

Hu, W., Chen, J. H., Wang, S. Y., Liu, J., \& Li, W. J. (2016). Changes in the physiological properties and kinetics of citric acid accumulation via carbon ion irradiation mutagenesis of Aspergillus niger. Journal of Zhejiang University-Science B, 17, 262-270. https://doi.org/10.1631/jzus.B1500120

IPCC. (1996). Climate change 1995. The science of climate change. Contribution of working group I to the second assessment report of the Intergovernmental Panel on Climate Change, Cambridge Uninversity Press, UK.

Jiang, L., Wang, J. F., Liang, S. Z., Wang, X. N., Cen, P. L., \& Xu, Z. N. (2009). Butyric acid fermentation in a fibrous bed bioreactor with immobilized Clostridium tyrobutyricum from cane molasses. Bioresour. Technol., 100, 3403-3409. https://doi.org/10.1016/j.biortech.2009.02.032

Kargi, F., Curme, J. A., \& Sheehan, J. J. (1985). Solid-state fermentation of sweet sorghum to ethanol. Biotechnol. Bioeng., 27, 34-40. https://doi.org/10.1002/bit.260270806

Kou, J. P., Bi, Y. Y., \& Zhao, L. X. (2008). Investigation and evaluation on wasteland for energy crops in China. Renewable Energy Resources, 26, 3-9. 
Kwon, Y., Wanga, F., \& Liu, G. (2011). Deep-bed solid state fermentation of sweet sorghum stalk to ethanol by thermotolerant Issatchenkia orientalis IPE 100. Bioresource Technol., 102, 11262-11265. https://doi.org/ 10.1016/j.biortech.2011.09.103

Laopaiboon, L., Thanonkeo, P., Jaisil, P., \& Laopaiboon, P. (2007). Ethanol production from sweet sorghum juice in batch and fed-batch fermentations by Saccharomyces cerevisiae. World J. Microbiol. Biotechnol., 23, 1497-1501. https://doi.org/10.1007/s11274-007-9383-X

Li, L. Q., Ma, L., \& Li, W. J. (2017). The selection for high-yield $\beta$-glucan production mutant strain by carbon ions irradiation. Food Science and Technology, 3, 2-6.

Li, Q. (2007). Biomedical research with heavy ions at the IMP accelerators. Adv. Space Res., 40, 455-460. https://doi.org/10.1016/j.asr.2007.03.096

Li, X. G., Li, F. M., \& Rengel, Z. (2006). Cultivation effects on temporal changes of organic carbon and aggregate stability in desert soils of Hexi Corridor region in China. Soil \& Tillage Research, 91, 22-29. https://doi.org/10.1016/j.still.2005.10.004

Li, Y. H., \& Lv, S. Q. (2015). Screening preemergence treatment herbicides for forage sweet sorghum. Sugar Crops of China, 37, 35-36.

Lu, D., Wang, Y., Liu, Q. F., Wu, X., Wang, J. F., Ma, S., \& Li, W. J. (2010). Improved ethanol fermentation of a yeast mutant by C-12 ion beam irradiation. Nuclear Techniques, 33, 350-353.

Ma, B. B., Wang, Z. Z., Wei, W., Dang, B. R., \& Li, W. J. (2016). Protection effects of carboxymethy- $\beta 1,3$-glucan on human B lymphoblasts' injury induced by radiation. J. Radiat. Res. Radiat. Process, 34(7), 020205.

Mocoeur, A., Zhang, Y. M., Liu, Z. Q., Shen, X., \& Jing, H. C. (2015). Stability and genetic control of morphological, biomass and biofuel traits under temperate maritime and continental conditions in sweet sorghum (Sorghum bicolour). Theor. Appl. Genet., 128, 1685-1701. https://doi.org/10.1007/s00122015-2538-5

Ning, H. X., \& Guo, F. H. (2015). Suitable planting division of sweet sorghum by CLRMIS in Wuwei Liangzhou Area. Sugar Crops of China, 37, 53-55.

Nyakatawa, E. Z., Mays, D. A., Tolbert, V. R., Green, T. H., \& Bingham, L. (2006). Runoff, sediment, nitrogen, and phosphorus losses from agricultural land converted to sweetgum and switchgrass bioenergy feedstock production in north Alabama. Biomass Bioenergy, 30, 655-664. https://doi.org/10.1016/j.biombioe. 2006.01.008

Phukoetphim, N., Salakkam, A., Laopaiboon, P., \& Laopaiboon, L. (2017). Improvement of ethanol production from sweet sorghum juice under batch and fed-batch fermentations: Effects of sugar levels, nitrogen supplementation, and feeding regimes. Electronic Journal of Biotechnology, 26, 84-92. https://doi.org/ 10.1016/j.ejbt.2017.01.005

Pimentel, D. (1992). Energy Inputs in Production Agriculture. In R. C. Fluck (Ed.), Energy in Farm Production (Vol. 6), In B. A. Stout (Ed.), Energy in World Agriculture (pp. 13-29). Elsevier Science, Amsterdam, NL. https://doi.org/10.1016/B978-0-444-88681-1.50007-7

Qiu, H. G., Huang, J. K., \& Yang, J. (2010). Bioethanol development in China and the potential impacts on its agricultural economy. Appl. Energy, 87, 76-83. https://doi.org/10.1016/j.apenergy.2009.07.015

Reddy, B. V., Ramesh, S., Reddy, P. S., \& Ramaiah, B. (2005). Sweet sorghum- a potential alternate raw material for bio-ethanol and bio-energy. International Sorghum and Millets Newsletter, 46, 79-86.

Regassa, T. H., \& Wortmann, C. S. (2014). Sweet sorghum as a bioenergy crop: Literature review. Biomass and Bioenergy, 64, 348-355. https://doi.org/10.1016/j.biombioe.2014.03.052

Rein, B. (1984). Fermentation of sweet sorghum juice as affected by heating and yeast inoculums (M.S. thesis, University of Nebraska, Lincoln, USA).

Ren, L. N. (2015). Stubble processing techniques for sweet sorghum cultivation. Sugar Crops of China, 37, 54-55.

Rooney, W. L., Blumenthal, J., Bean, B., \& Mullet, J. E. (2007). Designing sorghum as a dedicated bioenergy feedstock. Biofuels, Bioproducts and Biorefining, 1, 147-157. https://doi.org/10.1002/bbb.15 
RSB (Roundtable on Sustainable Biomaterials). (2013). Consolidated RSB EU RED principles and criteria for sustainable biofuel production.

Rutto, L. K., Xu, Y. X., Brandt, M., Ren, S. X., \& Kering, M. K. (2013). Juice, ethanol, and grain yield potential of five sweet sorghum (Sorghum bicolor [L.] Moench) cultivars. Journal of Sustainable Bioenergy Systems, 3, 113-118. https://doi.org/10.4236/jsbs.2013.32016

Sathre, R. (2014). Comparing the heat of combustion of fossil fuels to the heat accumulated by their lifecycle greenhouse gases. Fuel, 115, 674-677. https://doi.org/org/10.1016/j.fuel.2013.07.069

Sun, Z., Zhan, W. L., Guo, Z. Y., Xiao, G., \& Li, J. X. (2003). RIBLL, the radioactive ion beam line in Lanzhou. Nucl. Instrum. Meth. B, 107, 318-322. https://doi.org/10.1016/S0168-9002(03)01005-2

Tanaka, A. (1999). Mutation induction by ion beams in Arabidopsis. Gamma Field Symp., 38, 19-28.

Theuretzbacher, F., Bauer, A., Lizasoain, J., Friedl, A., Piringer, G., \& Gronauer, A. (2013). Potential of different Sorghum bicolor (L. Moench) varieties for combined ethanol and biogas production in the Pannonian climate of Austria. Energy, 55, 107-113. https://doi.org/10.1016/j.energy.2013.04.020

Tilman, D., Socolow, R., Foley, J., \& Williams, R. (2009). Beneficial biofuels - the food, energy, and environment trilemma. Science, 325, 270-271. https://doi.org/10.1126/science.1177970

Vasilakoglou, I., Dhima, K., Karagiannidis, N., \& Gatsis, T. (2011). Sweet sorghum productivity for biofuels under increased soil salinity and reduced irrigation. Field Crops Research, 120, 38-46. https://doi.org/ 10.1016/j.fcr.2010.08.011

Wang, F. L., Wang, J. R., \& Huang, S. X. (2013). Report of introduction demonstration experiment of sweet sorghum. Sugar Crops of China, 3, 47-49.

Wang, F. L., \& Yin, S. P. (2015). Culture techniques of sweet sorghum for water after sowing and drip irrigation under film mulching. Sugar Crops of China, 37, 56-57.

Wang, H. L., Niu, J. Y., \& Wang, R. Y. (2007). Agricultural resources and farmland productivity in different sections of Gansu Province. Agricultural Research in the Arid Areas, 25, 163-168.

Wang, J. F., Lu, D., Xu, X., Ma, S., \& Li, W. J. (2010). Inactive and mutagenic effects induced by carbon beams of different LET values in a red yeast strain. Nucl. Insrum. Meth. B, 268, 2719-2723. https://doi.org/10.1016/j.nimb.2010.05.100

Wang, Q. (2005). Development and utilization of the energy plant. J. Fujian Forestry Sci. and Tech., 32, 1-5.

Wang, S. Y., Zhang, X. Y., Su, H., Li, W. J., Xiao, G. Q., Chen, J. H., ... Liu, J. (2014). Influence on milk yield and milk composition of cows feed with sweet sorghum straw fermented by compound microbial agent in bags. Journal of Gansu Agricultural University, 2, 21-24. https://doi.org/10.4028/www.scientific.net/AMR. 690-693.1410

Wang, S. Y., Zhang, X. Y., Su, H., Xiao, G. Q., Li, W. J., Liang, J. P., \& Jiang, B. L. (2013). The influence on the milk yield and milk composition of the cows after feeding with the sweet sorghum straw fermented by the compound microbial agent in bags. Advanced Materials Research, 690-693, 1410-1413.

Wang, W. Q., Sun, X. B., Liu, J. R., \& Li, Y. D. (2016). Effect of different concentrations herbicide atrazine on weed and sweet sorghum biological yield. Sugar Crops of China, 38, 38-39.

Wang, Z. G. (2006). Materials research with swift heavy ions at the IMP accelerators. Nucl. Insrum. Meth. B, 245, 189-193. https://doi.org/10.1016/j.nimb.2005.11.099

Wu, L. F., Li, H., \& Yu, Z. L. (1999). The application of ion beam in life science. Acta Laser Biology Sinica, 18, 298-311.

Wu, X., Staggenborgb, S., Propheterb, J. L., Rooney, W. L., \& Yu, J. (2010). Features of sweet sorghum juice and their performance in ethanol fermentation. Ind. Crop Prod., 31, 164-170. https://doi.org/10.1016/ j.indcrop.2009.10.006

Wullschleger, S. D., Davis, E. B., Borsuk, M. E., Gunderson, C. A., \& Lynd, L. R. (2010). Biomass production in switchgrass across the United States: Database description and determinants of yield. Agron. J., 102, 1158-1168. https://doi.org/10.2134/agronj2010.0087

Yu, M., Stott, S., Toner, M., Maheswaran, S., \& Haber, D. A. (2011). Circulating tumor cells: Approaches to isolation and characterization. J. Cell Biol., 192, 373-382. https://doi.org/10.1083/jcb.201010021 
Zhang, M. M., Lu, D., Cao, G. Z., Jin, W. J., Wang, J. F., \& Li, W. J. (2013). Research of the effect of electron beam irradiation to aroma components in liquor. Science and Technology of Food Industry, 34, 103-106.

Zhang, S. R., \& Sun, X. B. (2015). Effects of different fertilizing amount on yield and quality of alcohol and forage sweet sorghum. Sugar Crops of China, 37, 41-42.

Zhang, X. L., Tang, T. X., Zhang, X. H., \& Wang, Z. Y. (2016). Effects of planting density on yield and sugar content of forage sweet sorghum. Sugar Crops of China, 38, 35-37.

Zhang, X. Y. (2015). Effect of black film mulching on weed control and yield of sweet sorghum. Sugar Crops of China, 37, 44-46.

Zhao, W. J., Zhang, F. Y., Chang, Y. H., Zhang, Y., Shao, R. F., \& Li, J. M. (2012). Effects of destooling on lodging of sweet sorghum. Chinese Agricultural Science Bulletin, 28, 84-87.

Zhao, X. Q., \& Bai, F. W. (2009). Mechanisms of yeast stress tolerance and its manipulation for efficient fuel ethanol production. J. Biotechnol., 144, 23-30. https://doi.org/10.1016/j.jbiotec.2009.05.001

Zhao, Y. L., Dolat, A., Steinberger, Y., Wang, X., Osman, A., \& Xie, G. H. (2009). Biomass yield and changes in chemical composition of sweet sorghum cultivars grown for biofuel. Field Crops Research, 111, 55-64. https://doi.org/10.1016/j.fcr.2008.10.006

Zhou, X., Yang, Z., Jiang, T. T., Wang, S. Y., \& Liang, J. P. (2016). The acquisition of Clostridium tyrobutyricum mutants with improved bioproduction under acidic conditions after two rounds of heavy-ion beam irradiation. Sci. Rep., 6, 29968. https://doi.org/10.1038/srep29968

\section{Copyrights}

Copyright for this article is retained by the author(s), with first publication rights granted to the journal.

This is an open-access article distributed under the terms and conditions of the Creative Commons Attribution license (http://creativecommons.org/licenses/by/4.0/). 